\title{
The Effect of Protein Source in Late Pregnancy Feed on the Occurrence of Agalactia Post Partum in the Sow
}

\author{
By Leif Göransson
}

Department of Animal Nutrition and Management, Swedish University of Agricultural Sciences, Uppsala, Sweden.

\begin{abstract}
Göransson, L: The effect of protein source in late pregnancy feed on the occurrence of agalactia post partum in the sow. Acta vet. scand. 1990. 31, 117-120. - The effect of an all vegetable protein diet on the occurrence of agalactia was studied. The experiment was performed in a commercial one thousand sow unit with an average frequency of agalactia of $50 \%$. The all vegetable diet significantly reduced the rectal temperature $48 \mathrm{~h}$ post partum and the number of medical treatments required. The litter size at weaning was larger $(p<0.05)$ in the group on the all vegetable protein diet.
\end{abstract}

late pregnancy feedig; protein feed.

\section{Introduction}

In several herds agalactia post partum is a considerable problem. In a Swedish investigation, Bäckström et al. (1975) found the frequency of agalactia to be $8.7 \%$. Danish workers recorded somewhat higher occurrences of agalactia (Nielsen et al. 1976, Jorsal 1983). Additionally Jorsal (1983) reported an increased incidence of joint inflammation and diarrhoea, and higher mortality in litters from sows treated for agalactia.

There is a well known relationship between late pregnancy feeding and incidence of agalactia. In order to minimize the risk of agalactia a common recommendation is to decrease the daily feed allowance 3-4 days prior to farrowing (Hultman 1973). In herds with severe agalactia problems a daily feed allowance of $1 \mathrm{~kg}$ in the last 3 weeks of pregnancy, clearly reduced the frequency of the disorder (Sandstedt \& Sjögren 1982, Göransson $1989 \mathrm{a})$. There is a risk however, that this type of feeding regime negatively affects the viability of the piglets. A high fibre diet in late pregnancy appeared to decrease the risk of agalactia (Wallace et al. 1974a, Göransson 1989b). Nachreiner \& Ginther (1972) and Wallace et al. (1974b) however, were not able to demonstrate any effect of high fibre diets in sow populations with normal frequencies of agalactia.

Furthermore an excess of protein in the late pregnancy diet can be a factor of importance. Sandstedt (1953) and Ringarp (1960) noticed less problems with agalactia when diets low in crude protein were fed prior to farrowing.

The objective of this experiment was to study the effect of feed protein origin in late pregnancy on the occurrence of agalactia post partum.

\section{Material and methods}

The experiment was performed in a commercial one thousand sow unit. The incidence of agalactia in the herd was at that time $50 \%$. Agalactia was defined as the state when the rectal temperature exceeded $39.4^{\circ} \mathrm{C}$ at any 
of the 4 morning and evening post partum measurements that routinely were performed.

The sows were fed a commercial barley based meal diet with a calculated ME content of $11.9 \mathrm{MJ} / \mathrm{kg}$ and $14.5 \%$ crude protein. Pregnant sows were fed $2.5 \mathrm{~kg}$ per day until 2 weeks prior to farrowing and $2.2 \mathrm{~kg}$ thereafter to farrowing. The feed allowance for lactating sows was successively increased during a period of 10 days after farrowing to a maximum of $2 \mathrm{~kg}$ plus $0.4 \mathrm{~kg}$ per piglet.

The experiment included 4 batches of 20 randomely selected sows that farrowed in cleaned pens. Batches No. 1 and 3 were given a standard diet with $5 \%$ fish meal and $1.5 \%$ meat and bone meal and batches No. 2 and 4 the experimental diet with only defatted soy bean meal as protein feed. The experimental diet was formulated to contain similar levels of crude protein, crude fibre and metabolizable energy as the standard feed mixture did. Both diets were fed during the last 3 weeks of pregnancy and during lactation.

Sows with a rectal temperature higher than $39.4^{\circ} \mathrm{C}$ (agalactic) were medically treated.
The number of piglets per litter was recorded at birth and at weaning.

The data on rectal temperatures were submitted to analysis of variance using the GLM procedure in SAS (Barr et al. 1979). The GLM procedure was also used when comparing the number of piglets born alive and the number of piglets weaned per litter. In these analyses the litter size at birth, stillborn included, was used as an independent variable.

\section{Results}

The number of piglets born alive was not affected by the protein source in late pregnancy diet (Table 1). The number of piglets weaned per litter from sows receiving the all vegetable protein diet, was however, significantly higher compared with the control group of sows.

The rectal temperatures on the third and fourth occassion of measuring were $0.4^{\circ} \mathrm{C}$ and $0.3^{\circ} \mathrm{C}$ higher in the group of sows fed the standard diet compared with the group fed the all vegetable protein diet. The occurrence of agalactia in the control group was

Table 1. The influence of protein source on litter size and rectal temperatures, means $(\overline{\mathbf{X}})$ and standard errors (SE).

\begin{tabular}{|c|c|c|c|c|c|}
\hline & \multicolumn{2}{|c|}{$\begin{array}{l}\text { Standard } \\
\text { diet }^{-}\end{array}$} & \multicolumn{2}{|c|}{$\begin{array}{l}\text { Vegetable } \\
\text { protein diet }\end{array}$} & \multirow[t]{2}{*}{$\begin{array}{c}\text { Level } \\
\text { of sign. }\end{array}$} \\
\hline & $\overline{\mathbf{x}}$ & SE & $\overline{\mathrm{x}}$ & SE & \\
\hline No. of litters & 40 & & 39 & & \\
\hline \multicolumn{6}{|l|}{ No. of piglets/litter } \\
\hline born & 10.6 & & 11.0 & & \\
\hline born alive ${ }^{++}$ & 10.4 & 0.11 & 10.5 & 0.11 & NS \\
\hline at weaning ${ }^{++}$ & 9.5 & 0.16 & 10.0 & 0.16 & * \\
\hline \multicolumn{6}{|c|}{ Rectal temperature, ${ }^{\circ} \mathrm{C}$} \\
\hline \multicolumn{6}{|c|}{ Measurement after farrowing } \\
\hline 1 st. & 38.9 & 0.09 & 38.8 & 0.09 & NS \\
\hline 2nd. & 39.0 & 0.11 & 38.8 & 0.11 & NS \\
\hline 3 rd. & 38.8 & 0.09 & 38.4 & 0.09 & $*$ \\
\hline 4th. & 39.0 & 0.09 & 38.7 & 0.10 & * \\
\hline
\end{tabular}

- with fish and bone meal

$+{ }^{*}=\mathrm{p}<0.05 ; \mathrm{NS}=$ not significant

++ least square means. 
$50 \%$ and in the vegetable protein group $30 \%$. This difference was almost statistically significant $(p=0.07)$.

\section{Discussion}

A possible causal mechanism of the agalactia syndrome, according to Ringarp (1960), can be an excessive protein feeding. According to his data not only the amount of protein but also the source of protein seemed to be of importance. In this investigation the effect of excluding fish meal and meat and bone meal from the late pregnancy diet on the frequency of agalactia was almost statistically significant and if differences in the third and fourth rectal temperature measurements are considered only, the effect of dietary protein origin was statistically significant $(\mathrm{p}<0.05)$.

Linneman et al. (1978) did not find any detrimental effect on the production traits in an experiment over 4 parities when the animal protein source was substituted by equivalent amounts of soy bean meal. In the present investigation, there seemed to be a negative effect on the number of piglets weaned per litter by feeding sows with animal protein feed stuffs. It is very likely that the higher mortality during the suckling period was an effect of the increased occurrence of agalactia. This is in good agreement with the results of Göransson (1989a) and Jorsal (1983).

\section{References}

Barr AJ, Goodnight JH, Sall JP, Blair WH, Chilko DM: SAS User's Guide. North Carolina, 1979.

Backström, L., Mattson J, Wallin O, Vilson B: Praktikjournalförsöket i Skaraborgs län 19711973. Retrospective analyses of veterinary records from the Skaraborg Country, 1971-1973. Sv. Vet. tidn. 1975, 7, 27.

Goransson L: The effect of feed allowance in late pregnancy on the occurrence of agalactia in the sow. J. Vet. Med. A, 1989a, in press.
Gorransson L: The effect of crude fibre content on the frequency of agalactia post partum in the sow. J. Vet. Med. A, 1989b, in press.

Hultman H: Avelsvinens utfodring. (Feeding of breeding pigs). Svin, 1973, LT: förlag, Stockholm.

Jorsal SE: Morbiditet hos Søer. (Morbidity in sows). Licentiatafhandlng, Institut for Intern Medicin. Den Kgl. Veterinær-och Landbohøjskole, København, 1983.

Linneman $F$, Danielsen $V$, Laursen $B$, Nielsen $H$ : Animalisk protein sammenlignet med vegetabilisk protein samt to niveauer af protein med tilskud af lysin og metionin til søer. (Animal protein compared with vegetable protein and two levels of protein supplemented with lysine and methionine to sows). Meddelelse Nr. 229, Statens Husdyrbrugsforsøg, København, 1978.

Nachreiner RF, Ginther OJ: Gestational and periparturient periods of sows: Effects of altered environment, witholding of bran feeding and induced mastitis on serum chemical, hematologic, and clinical variables. Amer. J. vet. Res. 1972, 33, 2221-2231.

Nielsen NC, Bille N, Svendsej J, Riisig H-J: Sygdomsbekæmpelse i svinebesætninger. (Disease control in swine herds). Institut for Intern Medicin. Den Kgl. Veterinær- og Landbohøjskole, København, 1976, 38-42.

Ringarp N: A post-parturient syndrome with agalactia in sows. Acta Agric. Scand. 1960, Supplementum 7, $166 \mathrm{pp}$.

Sandstedt $\mathrm{H}$ : Agalakti hos sugga. (Agalactia in the sow). Medlemsbl. Sveriges Vet. Forb. 1953, 5, 103.

Sandstedt $H$, Sjoggren $U$ : Förebyggande ătgărder vid hög frekvens av MMA i suggbesăttningar. (Prophylactic treatments in pig herds with a high frequency of agalactia). Sv. Vet. Tidn. 1982, 34, 487-490.

Wallace $H D$, Thieu $D D$, Combs $G E$ : Alfalfa meal as a special bulky ingredient in the sow diet at farrowing and during lactation. Research report, Dep. of Anim. Sci. Gainesville, Florida, 1974a.

Wallace HD, Thieu DD, Combs GE: Wheat bran as a sow ration ingredient during the farrowing and lactation period. Research report, Dep. of Anim. Sci. Gainesville, Florida, 1974b. 


\section{Sammanfattning}

Inverkan av ulika proteinfodermedel under sen dräktighet pả agalaktiförekomsten hos sugga.

Effekten av att byta animalt protein mot sojamjöl i fodret till suggor under sen dräktighet undersöktes. Försöket utfördes i en 1000 suggors besättning med en agalaktifrekvens på 50\%. Rektaltemperaturen inom 48 timmar efter grisning sjönk signifikant och antalet veterinärmedicinska behandlingar minskade hos suggor som fick fodret med enbart sojamjöl som proteinkälla. Antalet grisar per kull vid avvänjning var också större i denna grupp jämfört med gruppen som fick animalt protein i fodret.

(Received April 24, 1989; accepted June 1, 1989).

Reprints may be requested from: Leif Göransson, Swedish Pig Center, S-26800 Svalöv, Sweden. 